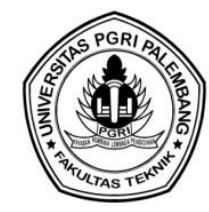

\title{
POTENSI ENERGI PEMBANGKIT LISTRIK TENAGA MIKRO HIDRO (PLTMH) NIAGARA DESA RANTAU NIPIS KECAMATAN BANDING AGUNG KABUPATEN OGAN KOMERING ULU SELATAN
}

\author{
Lindawati, Enda Kartika Sari*, Yuli Ermawati \\ Prodi Teknik Sipil, Fakultas Teknik dan Komputer, Universitas Baturaja \\ "Corresponding Author, Email : endaunbara@gmail.com
}

\begin{abstract}
ABSTRAK
Di Desa Rantau Nipis Kecamatan Banding Agung Kabupaten OKU Selatan terdapat aliran sungai yang memiliki potensi ketersediaan air yang cukup untuk sepanjang tahun, debit sungai yang dapat diandalkan, dan memiliki kontur yang sesuai dan telah dimanfaatkan untuk Pembangkit Listrik Tenaga Mikrohidro dinamakan Pembangkit Listrik Tenaga Mikrohidro Niagara. Namun, Pembangkit Listrik Tenaga Mikrohidro Niagara Desa Rantau Nipis ini sering mengalami penurunan daya listrik. Untuk itu perlu dilakukan analisis potensi energi dan waktu operasi efektif pada sistem Pembangkit Listrik Tenaga Mikrohidro Niagara Rantau Nipis. Tujuan dari penelitian ini adalah untuk mengetahui besar debit air sungai pada PLTMH Niagara Desa Rantau Nipis Kecamatan Banding Agung Kabupaten OKU Selatan dan mengetahui besar potensi sungai yang bisa dikembangkan untuk PLTMH Niagara Desa Rantau Nipis Kecamatan Banding Agung Kabupaten OKU Selatan. Metode yang dilakukan adalah metode survey dan pengamatan langsung di lapangan. Metode pengolahan dan analisis data untuk menghitung debit andalan dengan menggunakan metode Slove Area. Setelah didapat nilai debit andalan sungai dan debit terukur sungai, dilakukan perhitungan debit yang melalui pipa pesat yang digunakan untuk membangkitkan daya listrik. Debit pipa yang didapat digunakan untuk menghitung daya terbangkit PLTMH Niagara. Dari hasil penelitian ini didapatkan data perhitungan debit air sungai sebesar $16,43 \mathrm{~m}^{3} /$ detik. Jumlah kebutuhan energi listrik yang di butuhkan oleh PLTMH yang harus dikeluarkan selama 3 hari yaitu 1.916,0666 watt yang ada pada Kecamatan Banding Agung dan Mekakau Ilir.
\end{abstract}

Kata Kunci : Potensi; Debit Sungai; Pembangkit Listrik Mikro Hidro

\begin{abstract}
In Rantau Nipis Village, Banding Agung District, South OKU Regency, there is a river flow that has the potential for sufficient water availability throughout the year, reliable river discharge, and has appropriate contours and has been used for a Micro-hydro Power Plant called the Niagara Micro-Hydro Power Plant. However, the Niagara Microhydro Power Plant in Rantau Nipis Village often experiences a decrease in electrical power. For this reason, it is necessary to analyze the energy potential and effective operating time of the Niagara Rantau Nipis Microhydro Power Plant system. The purpose of this study was to determine the amount of river water discharge at PLTMH Niagara, Rantau Nipis Village, Banding Agung District, South OKU Regency and to find out the potential of the river that could be developed for PLTMH Niagara, Rantau Nipis Village, Banding Agung District, South OKU Regency. The method used is survey method and direct observation in the field. Data processing and analysis methods to calculate reliable discharge using the Slove Area method. After obtaining the mainstay discharge value of the river and the measured discharge of the river, a calculation of the discharge through the rapid pipe is carried out which is used to generate electrical power. The pipe discharge obtained is used to calculate the power generated by the Niagara PLTMH. From the results of this study, data obtained from the calculation of river water discharge of 16.43 m3/second. The amount of electrical energy needed by the PLTMH that must be issued for 3 days is 1,916.0666 watts in the Districts of Banding Agung and Mekakau Ilir.
\end{abstract}

Keywords : Potency; River Discharge; Micro Hydro Power Plant 


\section{PENDAHULUAN}

Sungai merupakan salah satu sumber air bagi kehidupan yang ada di bumi. Baik manusia, hewan dan tumbuhan, semua makhluk hidup memerlukan air untuk dapat mempertahankan kelangsungan hidupnya. Sungai mengalir dari hulu ke hilir bergerak dari tempat yang tinggi ke tempat yang rendah. Di Indonesia terdapat banyak sekali sungaisungai besar maupun kecil yang terdapat di berbagai daerah. Hal ini merupakan peluang yang bagus untuk mengembangkan energi listrik di daerah khususnya daerah yang belum terjangkau energi listrik.

Kebutuhan utama dalam kehidupan manusia adalah energi. Semakin besar energi dibutuhkan maka semakin maju suatu negara. Pada saat ini migas adalah sumber pengadaan energi yang jumlahnya terbatas dan suatu saat akan habis (Doda \& Mohammad 2018). Guna mengatasi permasalahan sumber energi yang semakin menipis perlu dilakukan pengembangan energi terbarukan, salah satunya yaitu pembangkit listrik tenaga air (PLTA) skala mikro atau mikrohidro (Pranoto et al 2018). Indonesia sebagai negara yang berada di garis khatulistiwa beriklim tropis dianugerahi banyak energi terbarukan dengan potensi mencapai 441,7 GW (Wardani 2017). Potensi tenaga air yang diperuntukkan untuk Pembangkit Listrik Tenaga Air (PLTA) dan Pembangkit Listrik Tenaga Mikrohidro sebesar 11\% yang tersebar di seluruh Indonesia (Dewan Energi Nasional 2016)

Solusi alternatif dalam memanfaatkan energi terbarukan yang dapat dioptimalkan penggunaannya seperti di pedesaan dan pegunungan yang belum mendapatkan akses jaringan tenaga listrik PLN dengan menggunakan energi listrik tenaga air. (Bawan et al 2021). Prinsip kerja PLTMH adalah air yang jatuh (debit) meter perdetik dan beda ketinggian yang mengalir melewati pipa, dimanfaatkan untuk menghasilkan daya listrik. (Baskoro et al 2021).

Pembangkit listrik tenaga air pada prinsipnya memanfaatkan beda ketinggian dan jumlah debit air per detik yang ada pada aliran air saluran irigasi, sungai atau air terjun. Aliran air ini akan memutar poros turbin sehingga menghasilkan energi mekanik. Energi ini selanjutnya menggerakan generator dan generator menghasilkan listrik. Pembangkit listrik mikro hidro mengacu pada pembangkit listrik dengan skala di bawah $200 \mathrm{~kW}$. Banyak daerah pedesaan di Indonesia yang yang dekat dengan aliran sungai sangat cocok untuk membuat pembangkit listrik pada skala dibawah $100 \mathrm{~kW}$ tersebut. Pemanfaatan potensi listrik mikro hidro di suatu daerah adalah untuk memenuhi kebutuhan energi dan mengantisipasi kenaikan biaya energi atau kesulitan jangkauan jaringan listik di daerah tersebut. Mikrohidro atau yang disebut dengan Pembangkit Listrik Tenaga Mikrohidro (PLTMH) adalah suatu pembangkit listrik skala kecil yang menggunakan tenaga air sebagai tenaga penggeraknya seperti saluran irigasi, sungai atau air terjun alam dengan cara memanfaatkan tinggi terjunan (head) dan jumlah debit air. Biasanya mikrohidro dibangun berdasarkan kenyataan bahwa adanya air yang mengalir di suatu daerah dengan kapasitas dan ketinggian yang memadai (Anonim 2008). Istilah kapasitas merujuk kepada jumlah volume aliran air persatuan waktu (flow capacity), sedangkan beda ketinggian daerah aliran sampai ke instalasi dikenal dengan istilah head. Mikrohidro juga dikenal sebagai white resources dengan terjemahan bebas bisa dikatakan "energi putih". Dikatakan 
demikian karena instalasi pembangkit listrik seperti ini menggunakan sumber daya yang telah disediakan oleh alam dan ramah lingkungan. (Rompas 2011)

Di Desa Rantau Nipis Kecamatan Banding Agung Kabupaten OKU Selatan terdapat aliran sungai yang memiliki potensi ketersediaan air yang cukup untuk sepanjang tahun, debit sungai yang dapat diandalkan, dan memiliki kontur yang sesuai dan telah dimanfaatkan untuk Pembangkit Listrik Tenaga Mikrohidro yaitu Pembangkit Listrik Tenaga Mikrohidro (PLTMH) Niagara. Tetapi PLTMH Niagara Desa Rantau Nipis ini sering mengalami penurunan daya listrik. Untuk itu perlu dilakukan analisis potensi energi dan waktu operasi efektif pada sistem PLTMH Niagara Rantau Nipis. Rumusan masalah dan tujuan dalam penelitian ini adalah berapa besar debit air sungai pada PLTMH Niagara Desa Rantau Nipis Kecamatan Banding Agung Kabupaten OKU Selatan dan berapa besar potensi sungai yang bisa dikembangkan untuk PLTMH Niagara Desa Rantau Nipis.

\section{METODE PENELITIAN}

Penelitian ini dilakukan pada Sungai Rantau Nipis, Kecamatan Banding Agung Kabupaten Ogan Komering Ulu Selatan. Data yang diperlukan terdiri dari data primer dan sekunder. Data primer yang dipakai untuk mendukung penelitian ini antara lain data debit Sungai Rantau Nipis pada titik bangunan PLTMH, data kecepatan aliran pada sungai hulu, hilir, tengah, di Sungai Rantau Nipis dan data tinggi muka air. Data sekunder yang dipakai untuk mendukung penelitian ini antara lain data perencanaan potensi PLTMH Niagara, peta Sungai Rantau Nipis, data kemiringan lereng, data tata guna lahan dan data curah hujan. Metode pengolahan dan analisis data untuk menghitung debit andalan dengan menggunakan metode Slove Area sebagai berikut:

$$
\begin{aligned}
\mathrm{Q} & =\mathrm{A} \cdot \mathrm{V} \\
\mathrm{V} & =\mathrm{P} / \mathrm{Xr} \\
\mathrm{A} & =\mathrm{Xr} \cdot \mathrm{br}
\end{aligned}
$$

Keterangan :

$$
\begin{aligned}
\mathrm{Q} & =\text { Debit } \\
\mathrm{A} & =\text { Luas penampang } \\
\mathrm{V} & =\text { Kecepatan } \\
\mathrm{Xr} & =\text { Waktu Tempuh Antar Titik } \\
\mathrm{Br} & =\text { Lebar Sungai Rata-rata } \\
\mathrm{Dr} & =\text { Keadalaman Basah Rata-rata }
\end{aligned}
$$

Setelah didapat nilai debit andalan sungai dan debit terukur sungai, dilakukan perhitungan debit yang melalui pipa pesat yang digunakan untuk membangkitkan daya listrik. Debit yang melalui pipa pesat dihitung pada kondisi debit pipa rencana dan debit pipa saat terjadi penurunan daya. Debit pipa yang didapat digunakan untuk menghitung daya terbangkit PLTMH Niagara. Hasil daya terbangkit yang didapat dilakukan perbandingan sehingga didapat persentase penurunan daya yang terjadi pada PLTMH Niagara. Perhitungan potensi pembangkit listrik PLTMH menggunakan rumus sebagai berikut :

$$
\mathrm{P}=\mathrm{p} \cdot \mathrm{n} \cdot \mathrm{g} \cdot \mathrm{Q} \cdot \mathrm{h}
$$


Keterangan :

$$
\begin{aligned}
\mathrm{P} & =\text { Watt } \\
\mathrm{p} & =\text { masa jenis air }\left(\mathrm{kg} / \mathrm{m}^{3}\right) \\
\mathrm{g} & =\text { gravitasi }\left(9,8 \mathrm{~m} / \mathrm{s}^{2}\right) \\
\mathrm{Q} & =\text { debit air }\left(\mathrm{m}^{3} / \text { detik }\right) \\
\mathrm{H} & =\text { head } / \text { ketinggian air }(\mathrm{m}) \\
\mathrm{n} & =\text { efisiensi turbin }
\end{aligned}
$$

\section{HASIL DAN PEMBAHASAN}

\section{Data Luasan Daerah Aliran Sungai (DAS)}

Dari segi hidrologi, Kabupaten Ogan Komering Ulu Selatan terbelah oleh Sungai Komering, di mana sungai ini merupakan sungai besar yang di aliri dua sungai lain yaitu Sungai Saka dan Sungai Selabung. Pada sungai-sungai besar tersebut masih terdapat sekitar 20 sungai dan anak sungai lainnya yang tersebar di seluruh wilayah Kabupaten Ogan Komering Ulu Selatan.

Di Kabupaten OKU Selatan juga terdapat beberapa air terjun dan danau, baik yang besar maupun kecil, sehingga daerah ini merupakan daerah pariwisata potensial di Provinsi Sumatera Selatan. Danau yang terbesar adalah Danau Ranau (Kecamatan Banding Agung), Danau Rakihan (Kecamatan Sindang Danau), Danau Halim (Kecamatan Buay Rawan) dan Danau Asmara (Kecamatan Simpang). Untuk kebutuhan operasionalnya PLTMH Niagara menggunakan aliran Sungai Selabung, dimana sungai ini berasal dari aliran Danau Ranau. Daerah aliran sungai yang ada di Kabupaten OKU Selatan dapat dilihat pada tabel 1 berikut

Tabel 1. Daerah Aliran Sungai Kabupaten Ogan Komering Ulu Selatan

\begin{tabular}{clc}
\hline No & Nama Daerah Aliran Sungai & Luas (ha) \\
\hline 1 & Sungai Saka & 6000 \\
2 & Sungai Gilas & 1200 \\
3 & Sungai Selulu & 3500 \\
4 & Sungai Magama & 2200 \\
5 & Sungai Pilamasin & 1500 \\
6 & Sungai Giham & 3000 \\
7 & Sungai Tahmi & 2000 \\
8 & Sungai Seliam & 9000 \\
9 & Sungai Furu & 1500 \\
10 & Sungai Imus & 4000 \\
11 & Sungai Buyuk & 2500 \\
12 & Sunagi Telema & 3000 \\
13 & Sungai Keruh & 2000 \\
14 & Sungai Selabung & 4400 \\
15 & Sungai Ruos & 2600 \\
16 & Sungai Ngepah & 1000 \\
17 & Sungai Mekakau & 4000 \\
18 & Sungai Beangtai & 1500 \\
19 & Sungai Kemu & 3500 \\
20 & Sungai Singau & 2300 \\
\hline
\end{tabular}


Lanjutan

\begin{tabular}{clc}
\hline No & Nama Daerah Aliran Sungai & Luas (ha) \\
\hline 19 & Sungai Kemu & 3500 \\
20 & Sungai Singau & 2300 \\
21 & Sungai Kisam & 5000 \\
22 & Sungai Luas Putih & 1500 \\
23 & Sungai Luas Besar & 2000 \\
24 & Sungai Are & 3000 \\
25 & Sungai Asaham & 1500 \\
26 & Sungai Meleki & 2000 \\
27 & Sungai Singalaga & 1000 \\
28 & Sunagi Limping & 1000 \\
29 & Sungai Keni & 2000 \\
\hline
\end{tabular}

Sumber:PT. Nusantara Indah Energindo, 2020

\section{Data Tata Guna Lahan}

PLTMH Niagara terletak pada area rumput, persawahan dan ladang. Dengan kebutuah lahan yang diperlukan untuk PLTMH Niagara dapat dilihat pada tabel 2 berikut.

Tabel 2. Lahan Yang Dibutuhkan Untuk PLTMH Niagara

\begin{tabular}{lcrrr}
\hline \multicolumn{1}{c}{ Nama PLTMH } & Panjang (m) & Lebar $(\mathbf{m})$ & Luas $\left(\mathbf{m}^{2}\right)$ & \multicolumn{1}{c}{ Luas (ha) } \\
\hline PLMH Niagara & & & & \\
a. Bendung & 47 & 27.53 & $1.313,5$ & 0.1313 \\
b. Intake & 100 & 9.23 & 923.15 & 0.092315 \\
c. Bak Penenang & 60 & 54.834 & 3290.077 & 0.032900 \\
d. Pipa Pesat & 50 & 15.901 & 795.0959 & 0.07909 \\
e. Gedung Sentral & 26 & 10.5 & 273.52 & 0.027352 \\
f. Jalan Akses & 135 & 5.98 & 807.454 & 0.090745 \\
g. Buffer Zone, dll & & & & 0.3027 \\
\hline
\end{tabular}

Sumber : PT.Nusantara Indah Energindo, 2020

\section{Data Curah Hujan Lima Tahun Terakhir}

Data curah hujan ini diambil dari Badan Pusat Statistik (BPS) Kabupaten OKU Selatan dalam kurun waktu 5 tahun terakhir dan dapat dilihat pada tabel 3 berikut.

Tabel 3. Data Rata rata Curah Hujan Pada DAS Banding Agung Kabupaten OKU Selatan

\begin{tabular}{clrrrrr}
\hline \multirow{2}{*}{ No } & \multirow{2}{*}{ Bulan } & \multicolumn{5}{c}{ Curah Hujan (MM) } \\
\cline { 3 - 7 } & & $\mathbf{2 0 1 5}$ & $\mathbf{2 0 1 6}$ & $\mathbf{2 0 1 7}$ & $\mathbf{2 0 1 8}$ & $\mathbf{2 0 1 9}$ \\
\hline 1 & Januari & 290 & 324,0 & 78 & 88,0 & \\
2 & Februari & 235 & 294,0 & 186 & 192,0 & 243,0 \\
3 & Maret & 248 & 556,0 & 174 & 144,0 & 114,0 \\
4 & April & 192 & 429,0 & 239 & 148,0 & 126,0 \\
5 & Mei & 124 & 288,0 & 227 & 96,0 & 86 \\
6 & Juni & 151 & 262,0 & 36 & 101,0 & 236,0 \\
7 & Juli & 77 & 210,0 & 18 & 25,0 & 124,0 \\
8 & Agustus & 22 & - & 92 & 39,0 & 27,0 \\
9 & September & 10 & 290,0 & 150 & 10,0 & 81,0 \\
\hline
\end{tabular}


lanjutan

\begin{tabular}{|c|c|c|c|c|c|c|}
\hline \multirow{2}{*}{ No } & \multirow{2}{*}{ Bulan } & \multicolumn{5}{|c|}{ Curah Hujan (MM) } \\
\hline & & 2015 & 2016 & 2017 & 2018 & 2019 \\
\hline 10 & Oktober & 0 & 440,0 & 70 & 24,0 & 0,0 \\
\hline 11 & November & 182 & 623,0 & - & 47,0 & 72,0 \\
\hline 12 & Desember & 522 & 253,0 & 118 & 51,0 & 309,0 \\
\hline & Jumlah & 2.053 & 3.969 & 1.388 & 965 & 1.611 \\
\hline & Rata-rata & 171,0 & 330,75 & 115,6 & 80,4 & 134,25 \\
\hline
\end{tabular}

\section{Kondisi Kelistrikan Kabupaten Ogan Komering Ulu Selatan}

Prasarana Jaringan Listrik di Kabupaten Ogan Komering Ulu Selatan berdasarkan data dari Dinas Pertambangan Propinsi Sumatera Selatan masih terdapat desa yang belum mendapatkan aliran listrik. Dari 10 kecamatan yang ada di Kabupaten OKU Selatan, dua Kecamatan yang desanya sudah berlistrik, sedangkan delapan kecamatan lainnya belum memiliki listrik.

Dari data tersebut tercatat ada 36 desa yang belum berlistrik yaitu tujuh desa di Kecamatan Muaradua, lima desa di Kecamatan Buay Pemacah, dan Buay Sandang Aji, satu desa di Kecamatan Buay Runjung, Kisam Tinggi dan Mekakau Ilir, tujuh desa di Kecamatan Muaradua Kisam dan 10 desa di Kecamatan Pulau Beringin. Dari uraian di atas dapat disimpulkan bahwa di kabupaten ini masih membutuhkan tambahan daya listrik untuk desa-desa tersebut di atas. Perkiraan kebutuhan energi listrik untuk rumah tangga di Kabupaten OKU Selatan dapat dilihat pada tabel 4 berikut :

Tabel 4. Perkiraan Kebutuhan Energi Listrik Rumah Tangga di Kab. OKUS

\begin{tabular}{|c|c|c|c|c|}
\hline No & Kecamatan & $\begin{array}{c}\text { Jumlah } \\
\text { Penduduk } \\
\text { (Jiwa) }\end{array}$ & $\begin{array}{c}\text { Jumlah Rumah } \\
\text { (Unit) }\end{array}$ & $\begin{array}{c}\text { Kebutuhan } \\
\text { Energi Listrik } \\
\text { (Watt) }\end{array}$ \\
\hline \multirow[t]{4}{*}{1} & Banding Agung & 72830 & 16.705 & $19.209,000$ \\
\hline & Rumah Tipe Kecil & & 10.023 & 9020,700 \\
\hline & Rumah Tipe Sedang & & 5.011 & 6514,300 \\
\hline & Rumah Tipe Besar & & 1.670 & 3674,000 \\
\hline \multirow[t]{5}{*}{2} & Mekakau Ilir & 22096 & 5.524 & $6.351,100$ \\
\hline & Rumah Tipe Kecil & & 3.314 & 2982,600 \\
\hline & Rumah Tipe Sedang & & 1.657 & 2154,100 \\
\hline & Rumah Tipe Besar & & 552 & 1214,400 \\
\hline & Jumlah & 94926 & 22.229 & $25.560,1$ \\
\hline \multirow[t]{4}{*}{3} & Pulau Beringin & 52942 & 11.509 & $13.235,600$ \\
\hline & Rumah Tipe Kecil & & 6.905 & 6214,500 \\
\hline & Rumah Tipe Sedang & & 3.453 & 4488,900 \\
\hline & Rumah Tipe Besar & & 1.151 & 2532,200 \\
\hline \multirow[t]{4}{*}{4} & Muara Dua Kisam & 32704 & 7.787 & 8955,400 \\
\hline & Rumah Tipe Kecil & & 4.672 & 4204,800 \\
\hline & Rumah Tipe Sedang & & 2.336 & 3036,800 \\
\hline & Rumah Tipe Besar & & 779 & 1713,800 \\
\hline
\end{tabular}


Lanjutan

\begin{tabular}{|c|c|c|c|c|}
\hline No & Kecamatan & $\begin{array}{c}\text { Jumlah } \\
\text { Penduduk } \\
\text { (Jiwa) }\end{array}$ & $\begin{array}{c}\text { Jumlah Rumah } \\
\text { (Unit) }\end{array}$ & $\begin{array}{c}\text { Kebutuhan } \\
\text { Energi Listrik } \\
\text { (Watt) }\end{array}$ \\
\hline \multirow[t]{4}{*}{5} & Kisam Tinggi & 21428 & 5.791 & 6659,400 \\
\hline & Rumah Tipe Kecil & & 3.475 & 3127,500 \\
\hline & Rumah Tipe Sedang & & 1.737 & 2258,100 \\
\hline & Rumah Tipe Besar & & 579 & 1273,800 \\
\hline \multirow[t]{4}{*}{6} & Muara Dua & 61118 & 13.286 & 15280,400 \\
\hline & Rumah Tipe Kecil & & 7.972 & 7174,800 \\
\hline & Rumah Tipe Sedang & & 3.986 & 5181,800 \\
\hline & Rumah Tipe Besar & & 1.329 & 2923,800 \\
\hline \multirow[t]{4}{*}{7} & Buay Sandang Aji & 32576 & 7.763 & 8928,700 \\
\hline & Rumah Tipe Kecil & & 4.654 & 4188,600 \\
\hline & Rumah Tipe Sedang & & 2.333 & 3032,900 \\
\hline & Rumah Tipe Besar & & 776 & 1707,200 \\
\hline \multirow[t]{4}{*}{8} & Buay Runjung & 31891 & 7.778 & 8944,800 \\
\hline & Rumah Tipe Kecil & & 4.667 & 4200,300 \\
\hline & Rumah Tipe Sedang & & 2.333 & 3032,900 \\
\hline & Rumah Tipe Besar & & 778 & 1711,600 \\
\hline \multirow[t]{4}{*}{9} & Simpang & 33369 & 8.139 & 9360,100 \\
\hline & Rumah Tipe Kecil & & 4.883 & 4394,700 \\
\hline & Rumah Tipe Sedang & & 2.442 & 3174,600 \\
\hline & Rumah Tipe Besar & & 814 & $1.790,80$ \\
\hline \multirow[t]{11}{*}{10} & Buay Pemacah & 42023 & 12.360 & $14.214,00$ \\
\hline & Rumah Tipe Kecil & & 7.416 & 6674,400 \\
\hline & Rumah Tipe Sedang & & 3.709 & 4820,400 \\
\hline & Rumah Tipe Besar & & 1.236 & 2719,200 \\
\hline & Kabupaten & 401976 & 96642 & 111139,800 \\
\hline & Rumah Tipe Kecil & & 57.981 & 52182,900 \\
\hline & Rumah Tipe Sedang & & 28.997 & $37.696,100$ \\
\hline & Rumah Tipe Besar & & 9.664 & $21.260,80$ \\
\hline & Penerangan Jalan (2\%) & & & $2.222,80$ \\
\hline & Cadangan (5\%) & & & $5.556,990$ \\
\hline & Total Kebutuhan & & & $118.919,59$ \\
\hline
\end{tabular}

Sumber : PT. Nusantara Indah Energindo, 2020

\section{Analisa perhitungan potensi pembangkit listrik tenaga mikro hidro}

\section{Perhitungan Kecepatan Aliran (V)}

Pengukuran perhitungan kecepatan aliran sungai dilakukan selama 3 hari dengan cara melemparkan bola pelampung ke setiap titik dengan menggunakan stopwatch sehingga dari setiap titik didapatkan hasil kecepatan aliran pada waktu yang dihitung dengan menghidupkan waktu pada stopwatch. Kecepatan aliran pada bendung sungai dapat dilihat pada tabel 5 berikut. 
Tabel 5. Kecepatan Aliran Pada Bendung Sungai

\begin{tabular}{ccccc}
\hline Hari & Waktu & $\begin{array}{c}\text { Kecepatan } \\
\text { Aliran (detik) }\end{array}$ & $\begin{array}{c}\text { Jumlah } \\
\text { (detik) }\end{array}$ & $\begin{array}{c}\text { Rata-rata } \\
\text { (detik) }\end{array}$ \\
\hline \multirow{2}{*}{ Senin } & Pagi & 45,80 & 105,03 & \\
& Sore & 59,23 & & \\
Selasa & Pagi & 300 & 653 & $\mathbf{2 4 3 , 3}$ \\
& Sore & 353 & & \\
Rabu & Pagi & 360 & 700 & \\
& Sore & 340 & &
\end{tabular}

Sumber : Pengolahan Data Primer, 2020

\section{Perhitungan Luas Penampang (A)}

Pengukuran perhitungan luas penampang aliran sungai dilakukan pada tiga titik atau tumpuan dengan cara mengukur memakai meteran, selanjutnya mengukur luas penampang dari titik 1 sampai dengan 3, kemudian mengukur kedalaman pada air menggunakan bambu yang panjang yang sudah dibatasi memakai meteran. Perhitungan luas penampang dapat dilihat pada tabel 6 berikut.

Tabel 6. Perhitungan Luas Penampang

\begin{tabular}{ccc}
\hline Titik (n) & Kedalaman $(\mathbf{m})$ & Lebar $(\mathbf{m})$ \\
\hline I & 3 & 11 \\
II & 2 & 15 \\
III & 9 & 20 \\
\hline Jumlah & 14 & 46 \\
\hline Rata-rata & $\mathrm{Xr}=4,66$ & $\mathrm{Br}=15,33$ \\
\hline Sumber $:$ Data Primer Diolah 2020
\end{tabular}

Sumber : Data Primer Diolah, 2020

\section{Perhitungan Debit Air (Q)}

Jumlah air yang mengalir dalam saluran atau sungai per unit waktu disebut dengan debit. Metode yang sering digunakan untuk menetapkan debit sungai adalah metode profil sungai (cross section) (Marhendi 2019). Menentukan debit air dilakukan dengan cara bola pelampung diisi air sedikit sehingga bola stabil, kemudian bola dilemparkan dari titik awal dan akhir, sehingga setiap titik didapat hasil dari luas x kecepatan pada aliran. Perhitungan debit didapat dari persamaan :

$$
\begin{aligned}
\mathrm{Q} & =\mathrm{A} . \mathrm{V} \\
\mathrm{Q} & =71,44 \times 0,25 \\
& =16,43\left(\mathrm{~m}^{3} / \text { detik }\right)
\end{aligned}
$$

Prinsip kerja pada PLTMH yaitu air yang jatuh (debit) meter perdetik dan beda ketinggian yang mengalir melewati pipa, dimanfaatkan untuk menghasilkan daya listrik. (Baskoro et al 2021). Pembangkit listrik tenaga mikro hidro merupakan kebutuhan yang sangat diharapkan oleh penduduk khususnya di daerah pedesaan yang potensi airnya melimpah, dengan potensi kelistrikannya yang ramah lingkungan, sehingga dapat mewujudkan energi yang bersih, sehat, dan terkontrol dengan suatu sistem, seperti dengan data berikut : 
a) PLTMH Niagara ini memakai jenis turbin pelton dimana dalam penelitian dilakukan pengukuran tinggi jatuh air dengan menggunakan meteran

b) Pengukuran dilakukan dari bak penampung (ferebay) ke lokasi turbin PLTMH (turbine) dengan cara memakai meteran untuk mengukur ketinggian,

c) Dalam pengukuran tinggi jatuh air didapat $14 \mathrm{~m}$ dengan ukuran pipa pesat yang berukuran panjang 70 meter, dari hasil penelitian debit air yang didapatkan sebesar $16,43 \mathrm{~m}^{3} /$ detik.

d) Jenis turbin pleton PLTMH ini memiliki efisiensi sebesar 0,85

e) Masa jenis air PLTMH niagara ini yaitu $1000 \mathrm{~kg} / \mathrm{m}^{3}$ dari hasil perencanaan pada tahun 2015

Dengan potensi pembangkit listrik PLTMH ini sebagai berikut

$$
\begin{aligned}
\mathrm{P} & =\mathrm{p} \cdot \mathrm{n} \cdot \mathrm{g} \cdot \mathrm{Q} \cdot \mathrm{h} \\
& =1000 \times 0,85 \times 9,8 \times 16,43 \times 14 \\
& =1.916 .066 \mathrm{watt}
\end{aligned}
$$

\section{KESIMPULAN}

Dari hasil penelitian ini didapatkan data perhitungan debit air sungai sebesar 16,43 $\mathrm{m}^{3} /$ detik. Jumlah kebutuhan energi listrik yang di butuhkan oleh PLTMH yang harus dikeluarkan selama 3 hari yaitu 1.916,0666 watt dan terjadi pada Kecamatan Banding Agung dan Mekakau Ilir

\section{DAFTAR PUSTAKA}

Anonim. 2008. Buku 2B. Pedoman Kelayakan Sipil. Jakarta: Direktorat Jendral Listrik dan Pemanfaatan Energi Departemen Energi dan Sumber Daya Mineral.

Baskoro, F., Murtadlo, I., \& Wrahatnolo, T. (2021). Analisa Kelayakan Pembangkit Listrik Tenaga Mikrohidro (PLTMH) di Embung Kuniran Kecamatan Sine Kabupaten Ngawi. Jurnal Teknik Elektro, 10(3), 783-791.

Bawan, E. K. (2021). Analisa Potensi Energi Terbarukan Pembangkit Listrik Tenaga Mikrohidro (PLTMH) di Manokwari Selatan. Jurnal Penelitian Saintek, 26(1).

Dewan Energi Nasional. 2016. Outlook Energi Indonesia. Jakarta

Doda, N., \& Mohammad, H. (2018). Analisis potensi pengembangan pembangkit listrik tenaga mikrohidro di Kabupaten Bone Bolango. Gorontalo Journal of Infrastructure and Science Engineering, 1(1), 1-10.

Marhendi, T. (2019). Studi Potensi Pembangkit Listrik Tenaga Mikro Hidro Di Sungai Brukah (Kali Bening, Banjarnegara). Techno (Jurnal Fakultas Teknik, Universitas Muhammadiyah Purwokerto), 20(1), 10-16.

Pranoto, B., Aini, S. N., Soekarno, H., Zukhrufiyati, A., Al Rasyid, H., \& Lestari, S. (2018). Potensi Energi Mikrohidro di Daerah Irigasi (Studi Kasus di Wilayah Sungai Serayu Opak). Jurnal Irigasi, 12(2), 77-86. 
Rompas, P. T. (2011). Analisis pembangkit listrik tenaga mikrohidro (pltmh) pada daerah aliran sungai ongkak mongondow di desa muntoi kabupaten bolaang mongondow. Jurnal Penelitian Saintek, 16(2), 160-171.

Wardani. 2017. Pertumbuhan Listrik EBT Terus Digenjot. https://ebtke.esdm.go.id/post/2017/10/03/1762/pertumbuhan.pembangkit.listrik.ebt .terus.digenjot, diakses tanggal 1 Maret 2021 